\title{
Erratum to: The carboxy-terminal half of nonstructural protein 3A is not essential for foot-and-mouth disease virus replication in cultured cell lines
}

\author{
Mrutyunjay Behura $^{1} \cdot$ Jajati K. Mohapatra $^{1} \cdot$ Laxmi K. Pandey $^{1} \cdot$ \\ Biswajit Das $^{1} \cdot$ Mukesh Bhatt $^{1} \cdot$ Saravanan Subramaniam $^{1} \cdot$ Bramhadev Pattnaik $^{1}$
}

Published online: 2 April 2016

(C) Springer-Verlag Wien 2016

\section{Erratum to: Arch Virol}

DOI 10.1007/s00705-016-2805-z

Unfortunately, the article title was incorrectly published in the original version and the same is corrected here. The original article has been updated accordingly.

The online version of the original article can be found under doi:10.1007/s00705-016-2805-z.

\footnotetext{
Jajati K. Mohapatra

jajati1@gmail.com

1 ICAR-Project Directorate on Foot and Mouth Disease,

Mukteswar 263 138, Uttarakhand, India
} 